\title{
Insect faunal succession on buried goat carcass in Aligarh Region of Uttar Pradesh, India, with implications in forensic entomology
}

\author{
Swaima Sharif and Ayesha Qamar ${ }^{*}$ (1)
}

\begin{abstract}
Background: Studies on the insect fauna of animal corpses, used as a vertebrate model, may help forensic investigation cases to estimate the post-mortem-interval (PMI), cause of death, and crime-scene location. Likewise, entomofauna of buried corpses can assist in determining the post-burial-interval (PBI), movement of the body or hiding of the crime. The bodies buried under the soil decompose at a slower rate than the body exposed. Also, there are fewer insects that can go underground to locate the corpse. Such types of studies on the insect fauna of buried carrion can help in forensic investigation cases. The current study aims to determine the succession of a goat carcass buried shallowly in an outdoor habitat of the Aligarh Region, North India.
\end{abstract}

Results: In the present study, we examined a goat carcass buried at a depth of nine inches to determine the type of insects capable of colonizing buried animal carcass in the study area of Aligarh, Uttar Pradesh, India. We have found five species of Diptera, three species of Coleoptera, one Hemipteran species, and one Hymenopteran species. Adult Dipterans found during different samplings were Megaselia scalaris (Loew 1866), Chrysomya megacephala (Fabricius 1794), and Calliphora vicina (Robineau-Desvoidy, 1830). Dipterans' immature stages were found to be of Synthesiomyia nudiseta (van der Wulp, 1883) and Hydrotaea capensis (Wiedemann, 1830) Megaselia scalaris. Adults of Saprinus quadriguttatus (Fabricius, 1798), Saprinus splendens (Paykull, 1811), and Onthophagous quadridentatus (Fabricius, 1798) of order Coleoptera. Adult Cydnus species (Fabricius, 1803) of Hemiptera and Dorylus species (Fabricius, 1793) of Hymenoptera have also been recorded. During the sampling, the authors reported the stages of carcass disintegration and the insects associated with it.

Conclusions: Flies, beetles, and ants have been recorded in association with the buried goat carcass, which may add to the knowledge of colonization of buried bodies in India and around the globe. S. nudiseta, H. capensis, and M. scalaris, which are found on the goat carrion in the current study, have also been reported on human corpses in the past. Furthermore, $M$. scalaris found consistently on two sampling dates beneath the ground on the goat carcass and was also seen running on the grave's surface. In addition, authors have reported several species belonging to different order and families, corresponding to various stages of decomposition of corpse which were earlier not known from buried corpses from India. So, it is crucial and may have implications in medicolegal cases.

Keywords: Buried goat carcass, Faunal succession, Forensic Entomology, Decomposition stages

\footnotetext{
* Correspondence: ayesha.zoology@gmail.com

Section of Entomology, Department of Zoology, Aligarh Muslim University, Aligarh, U.P, India
}

\section{Springer Open}

(๑) The Author(s). 2021 Open Access This article is licensed under a Creative Commons Attribution 4.0 International License, which permits use, sharing, adaptation, distribution and reproduction in any medium or format, as long as you give appropriate credit to the original author(s) and the source, provide a link to the Creative Commons licence, and indicate if changes were made. The images or other third party material in this article are included in the article's Creative Commons licence, unless indicated otherwise in a credit line to the material. If material is not included in the article's Creative Commons licence and your intended use is not permitted by statutory regulation or exceeds the permitted use, you will need to obtain permission directly from the copyright holder. To view a copy of this licence, visit http://creativecommons.org/licenses/by/4.0/. 


\section{Background}

The present study aims to analyze the insect succession and decomposition rate of a shallowly buried goat carcass in North Indian climatic conditions for two years. During putrefaction, corpses undergo considerable physical, chemical, and biological changes. Each decomposition stage is attractive to a group of arthropods, predominantly sarcosaprophagous insects such as Dipterans, Coleopterans, Hemipterans, Hymenopterans, and numerous others. Amongst these, Dipterans are the first ones to arrive on dead and decaying animal or human corpses, followed by Coleopterans, Hymenopterans, and Hemipterans.

Physical barriers such as soil cover or burial, body enclosed in containers/suitcases/drums, wrapped in clothing or sacs, and various others may hamper the insect activity. Time taken by insects to colonize the carrion placed above ground would be less than the carrion buried underground. Often, it has been seen that criminals bury the dead in shallow graves in haste, as digging requires much time and effort. Shallow grave entomofauna may also vary from the deep graves as some insects which can reach the thin soil cover may not locate the corpse buried deep (cited by Lundt, 1964).

Forensic entomology is a wide field of science that uses insect shreds of evidence in medicolegal investigations. The field has not only been confined to death investigations but also includes its broader aspects like in child/elderly neglect cases (Beneckea et al. 2009), unfit stored food products (Hagstrum and Athanassiou 2019), poor hygienic conditions of restaurants, and wildlife poaching cases (Anderson 1999). A thorough knowledge about insects can provide essential and valuable information regarding the cause and time of death. The diversity and succession of insects depend on several factors such as physical barriers, chemicals or toxins (Keshavarzi and Rassi, 2020), size, indoor/outdoor (Keshavarzi et al. 2019) and body mass of the corpse. Experiments conducted on flesh or animal tissue pieces may be misleading as the whole carcass has more surface area and body mass, resulting in a greater assemblage of insects than on an amount of animal tissue (LeBlanc et al., 2021). In addition, seasonal variations also influence the species richness and diversity of insects colonizing a corpse (Keshavarzi and Rassi 2020). In cases of pertinent death investigations, it requires the combined testimonies from various disciplines- from autopsy surgeon to forensic pathologist and other medical non-medical professionals. When a body is infested with insects, they must be collected in congruency with other biological evidence. These creatures could prove to be a vital parameter to many unanswered questions to the case mysteries.

\section{Methods \\ Study site}

The study was conducted in India, West of Uttar Pradesh, district Aligarh, microlocality Dhorra mafi. $27^{\circ} 54^{\prime}$ $41.96^{\prime \prime} \mathrm{N}$ and $78^{\circ} 4^{\prime} 25.4^{\prime \prime} \mathrm{E}$, comprising a land area of $60^{\prime} \times 37^{\prime}$ with vegetation of mulberries, brinjal, papaya, and mango on loamy soil. The average annual rainfall is $75.4 \mathrm{~cm}$, and the average annual maximum and minimum temperatures are $31.30{ }^{\circ} \mathrm{C}$ and $17.90{ }^{\circ} \mathrm{C}$, respectively. Relative Humidity (RH) values are about 61 to $84 \%$ in the morning and $46 \%$ to $75 \%$ in the afternoon during the southwest monsoon season (data retrieved from http://www.imdpune.gov.in/caui/smartcities/ALIGARH. pdf). It has three distinct seasons in terms of temperature conditions.

\section{Study time}

The period of the study is from early February 2018 to late March 2020.

\section{Carrion}

A fresh female, dead goat Capra hircus (Artiodactyla: Bovidae), was found on the 9th of February 2018. The death occurred due to the wound at its neck caused by the attack of some stray dogs. The goat age was about 3 months, the length was $22.5^{\prime \prime}$ from head to the start of tail, weight $8.6 \mathrm{~kg}$, and body temperature $27{ }^{\circ} \mathrm{C}$ at the time of burial.

\section{Examination procedure and taxonomic identification}

The body was buried in a rectangular grave of dimensions $3^{\prime} 9^{\prime \prime} \times 2^{\prime} 9^{\prime \prime} \times 9^{\prime \prime}$ (Length $\times$ Breadth $\times$ Depth). The soil temperature of the lowermost depth of the grave was found to be $15{ }^{\circ} \mathrm{C}$. The air temperature was $24{ }^{\circ} \mathrm{C}$ maximum and $8{ }^{\circ} \mathrm{C}$ minimum. The grave was in direct contact with the sunshine. The grave was opened and sampled every week from fresh to the late dry stage for collection and observation of insects. Afterward, it was sampled after 3 months, then followed by 6 months. Immature stages of insects were collected gently by using forceps and brushes and preserved in 70\% ethanol. Adults were collected with the help of a small sweep net, particularly the Dipterans. Adult Coleopterans and Hemipterans were collected by handpicking with forceps and by sieving the soil. In addition, some of the immature stages of flies were reared in the laboratory at $27 \pm$ $2{ }^{\circ} \mathrm{C}$ on goat meat up to the adult stage for identification purposes. The collected fauna was identified with the help of the taxonomic keys (Sawaby et al. 2018 and Carvalho, 2008) and later confirmed by the Zoological Survey of India, Kolkata. 
Table 1 Summary of results with date of sampling, fauna collected, site of collection of insects, temperature, and RH of air

\begin{tabular}{|c|c|c|c|c|c|}
\hline Date of sampling & $\begin{array}{l}\text { State of } \\
\text { body }\end{array}$ & Fauna collected & $\begin{array}{l}\text { Stage of insect/site of } \\
\text { collection }\end{array}$ & $\begin{array}{l}\text { Temperature } \\
\text { (air) }\end{array}$ & $\begin{array}{l}\text { Relative } \\
\text { humidity RH (Air) }\end{array}$ \\
\hline 9 February 2018 & Fresh & Nil & $\ldots . . .{ }^{a}$ & $24{ }^{\circ} \mathrm{C}$ & $42 \%$ \\
\hline $\begin{array}{l}16 \text { February } 2018 \\
\text { (first sampling) }\end{array}$ & Fresh & $\begin{array}{l}\text { (a) Megaselia scalaris } \\
\text { (b)Onthophagous quadridentatus } \\
\text { (c) Cydnus sp. (fauna found inside). }\end{array}$ & $\begin{array}{l}\text { (a) Adults running over the top } \\
\text { of the grave and present inside } \\
\text { the grave on the back of the } \\
\text { carcass. } \\
\text { (b) Adults, not present on the } \\
\text { body, but into the soil of grave. } \\
\text { (c) Adults, not present on the } \\
\text { body, but into the soil of grave. }\end{array}$ & $25^{\circ} \mathrm{C}$ & $48 \%$ \\
\hline $\begin{array}{l}23 \text { February } 2018 \\
\text { (2nd sampling) }\end{array}$ & Bloated & $\begin{array}{l}\text { (d) Megaselia scalaris } \\
\text { (e) Chrysomyia megacephala and Calliphora } \\
\text { vicina } \\
\text { (f) Saprinus quadriguttatus } \\
\text { (g) Cydnus sp. were collected inside the grave }\end{array}$ & $\begin{array}{l}\text { (d) Adults found running at the } \\
\text { surface of the grave. } \\
\text { (e) Adults collected when the } \\
\text { grave was opened and body } \\
\text { was exposed. } \\
\text { (f) Adults, not present on the } \\
\text { body, but into the soil of grave. } \\
\text { (g) Adults, not present on the } \\
\text { body, but into the soil of grave. }\end{array}$ & $30^{\circ} \mathrm{C}$ & $61 \%$ \\
\hline $\begin{array}{l}02 \text { March } 2018 \\
\text { (3rd sampling) }\end{array}$ & $\begin{array}{l}\text { Active } \\
\text { decay }\end{array}$ & $\begin{array}{l}\text { (h) Maggots collected and reared into the } \\
\text { laboratory. } \\
\text { (i) Dorylus sp. collected. } \\
\text { (j) Saprinus quadriguttatus and Saprinus } \\
\text { splendens collected. }\end{array}$ & $\begin{array}{l}\text { (h) 2nd instars of Hydrotaea } \\
\text { capensis and 3rd instars of } \\
\text { Synthesiomyia nudiseta } \\
\text { collected from the deflated } \\
\text { abdominal region. } \\
\text { (i) Colony of ants in numbers } \\
\text { were present inside the grave } \\
\text { on the animal carcass where } \\
\text { maggots were present. } \\
\text { (j) Adults were present inside } \\
\text { the grave. }\end{array}$ & $31^{\circ} \mathrm{C}$ & $34 \%$ \\
\hline $\begin{array}{l}09 \text { March } 2018 \\
\text { (4th sampling) }\end{array}$ & $\begin{array}{l}\text { Post } \\
\text { decay }\end{array}$ & Larvae were still observed with cocoons & $\begin{array}{l}\text { Cocoon of Synthesiomyia } \\
\text { nudiseta in the soil of grave } \\
\text { and larvae of Hydrotaea were } \\
\text { collected. }\end{array}$ & $31^{\circ} \mathrm{C}$ & $27 \%$ \\
\hline $\begin{array}{l}16 \text { March } 2018 \\
\text { (5th sampling) }\end{array}$ & Dry & $\begin{array}{l}\text { Very few maggots and more of cocoons were } \\
\text { observed and collected. }\end{array}$ & $\begin{array}{l}\text { Larvae of } H \text {. capensis and } \\
\text { coccons of S.nudiseta and } H \text {. } \\
\text { capensis collected from the soil } \\
\text { inside the grave. }\end{array}$ & $30^{\circ} \mathrm{C}$ & $62 \%$ \\
\hline $\begin{array}{l}23 \text { March } 2018 \\
\text { (6th sampling) }\end{array}$ & Dry & Live and empty puparia were observed. & $\begin{array}{l}\text { Live puparia of } H \text {. capensis and } \\
\text { empty puparia of } \mathrm{S} \text {. nudiseta } \\
\text { inside the grave. }\end{array}$ & $31^{\circ} \mathrm{C}$ & $49 \%$ \\
\hline $\begin{array}{l}25 \text { April } 2018\left(7^{\text {th }}\right. \\
\text { sampling) }\end{array}$ & Dry & Empty puparial cases & $\begin{array}{l}\text { Puparial cases of } H \text {. capensis } \\
\text { and S. nudiseta }\end{array}$ & $38^{\circ} \mathrm{C}$ & $54 \%$ \\
\hline $\begin{array}{l}25 \text { May } 2018 \\
\text { (8th sampling) }\end{array}$ & Dry & Empty puparial cases & $\begin{array}{l}\text { Puparial cases of } H \text {. capensis } \\
\text { and S. nudiseta }\end{array}$ & $40{ }^{\circ} \mathrm{C}$ & $78 \%$ \\
\hline $\begin{array}{l}26 \text { August } 2018 \\
\text { (9th sampling) }\end{array}$ & Dry & No fauna & $+\cdots+\cdots$ & $41^{\circ} \mathrm{C}$ & $90 \%$ \\
\hline $\begin{array}{l}21 \text { November } \\
2018 \\
\text { (10th sampling) }\end{array}$ & Dry & No fauna & $\ldots \ldots \ldots$ & $20^{\circ} \mathrm{C}$ & $73 \%$ \\
\hline $\begin{array}{l}24 \text { February } 2019 \\
\text { (11th sampling) }\end{array}$ & Dry & No fauna & $\ldots \ldots \ldots$ & $24{ }^{\circ} \mathrm{C}$ & $62 \%$ \\
\hline $\begin{array}{l}25 \text { August } 2019 \\
\text { (12th sampling) }\end{array}$ & Dry & No fauna & $\ldots \ldots \ldots$ & $42^{\circ} \mathrm{C}$ & $80 \%$ \\
\hline $\begin{array}{l}28 \text { March } 2020 \\
\text { (13th sampling) }\end{array}$ & Dry & No fauna & $\ldots \ldots$ & $28^{\circ} \mathrm{C}$ & $56 \%$ \\
\hline
\end{tabular}

${ }^{\mathrm{a} N o}$ insects present 

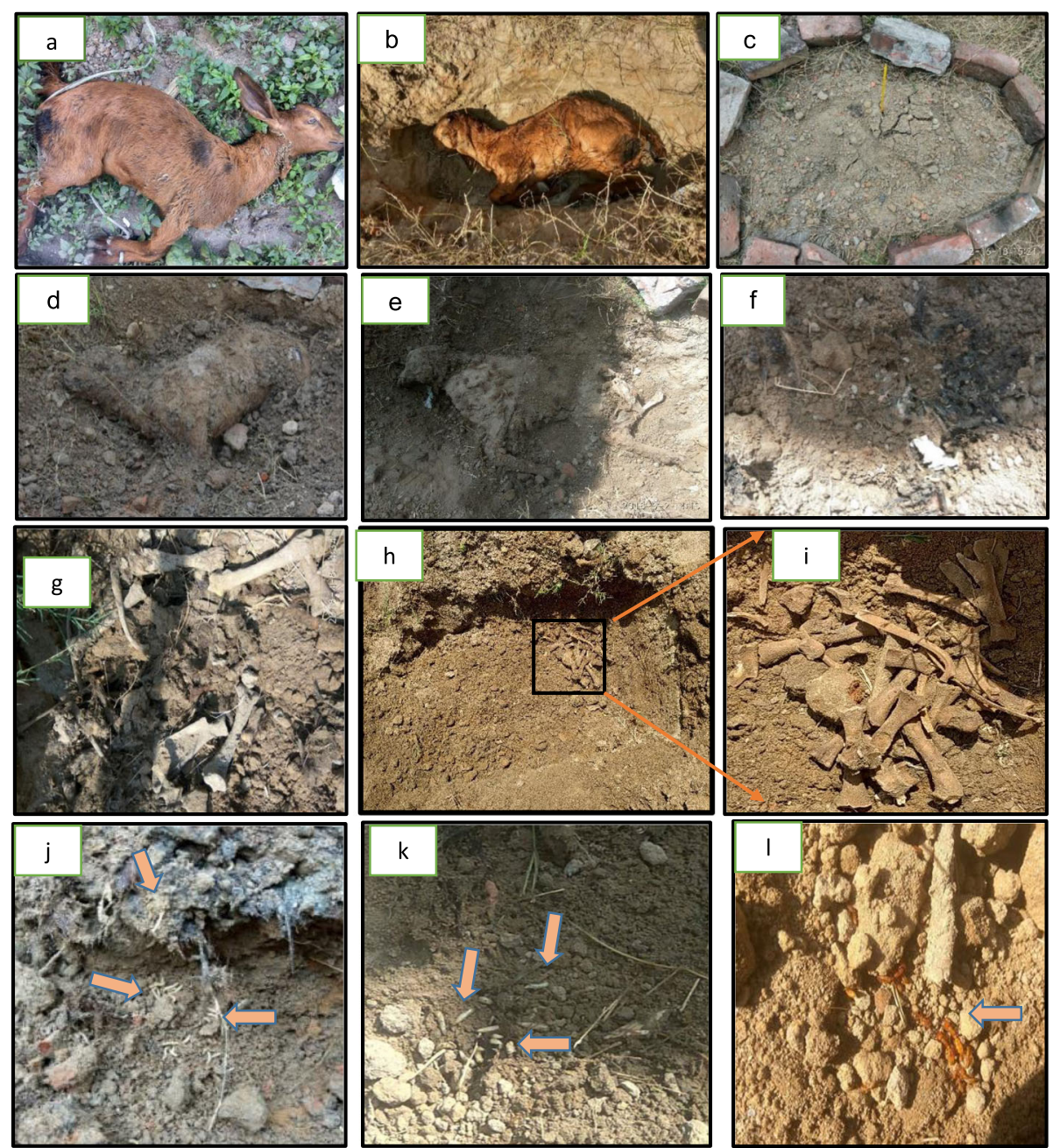

Fig. 1 Stages of decomposition of buried goat carcass. a Fresh carcass. b Carcass placed inside the grave. c Top view of the grave. $\mathbf{d}$ Bloated stage of carcass. e Deflated carcass. $\mathbf{f}$ Active decay. $\mathbf{g}$ Dry stage. $\mathbf{h}$ Late dry stage. i Enlarged view of the bones (no skin or hairs). $\mathbf{j}$, $\mathbf{k}$ Maggots inside the grave. I Aggregation of ants inside the grave

\section{Results}

The current study documented that the insects found on buried goat carcass which belong to four orders-Diptera, Coleoptera, Hymenoptera, and Hemiptera; seven families-Phoridae, Calliphoridae, Muscidae of Diptera, Histeridae, and Scarabaeidae of Coleoptera, Cydnidae of Hemiptera, and Formicidae of Hymenoptera. Diptera includes adults of Chrysomyia megacephala (Calliphoridae) and Calliphora vicina (Calliphoridae), adults, and cocoons of Megaselia scalaris (Phoridae), larvae of Synthesiomyia nudiseta (Muscidae), and Hydrotaea capensis (Muscidae) (clips 1 and 2 in additional/Supplementary files). Coleoptera includes adults of Saprinus quadriguttatus (Histeridae), Saprinus splendens (Histeridae), and Onthophagous quadridentatus (Scarabaeidae). Adult Cydnus sp. of Hemiptera and Dorylus sp. of Hymenoptera have also been reported.

\section{Decomposition stages of goat carcass and insects associated}

The carcass had undergone five stages of decomposition-fresh, bloated, active decay, post-decay, and dry stage. It took around 5 weeks from the fresh stage to reach to dry stage. The fresh phase lasted for about 1 week. Insects found to be associated with this stage during the first sampling (1 week after burial) were adults of Megaselia scalaris, Onthophagous quadridentatus, and Cydnus sp. During the second sampling (2 weeks after burial), the body was in the bloated stage. The fauna collected were adults of Megaselia scalaris, Saprinus quadriguttatus, and Cydnus sp. When the grave was opened and the carcass was exposed during sampling, Chrysomyia megacephala and Calliphora vicina were observed visiting the dead but could not oviposit. Immature stages of Synthesiomyia nudiseta (Muscidae) and larvae of 


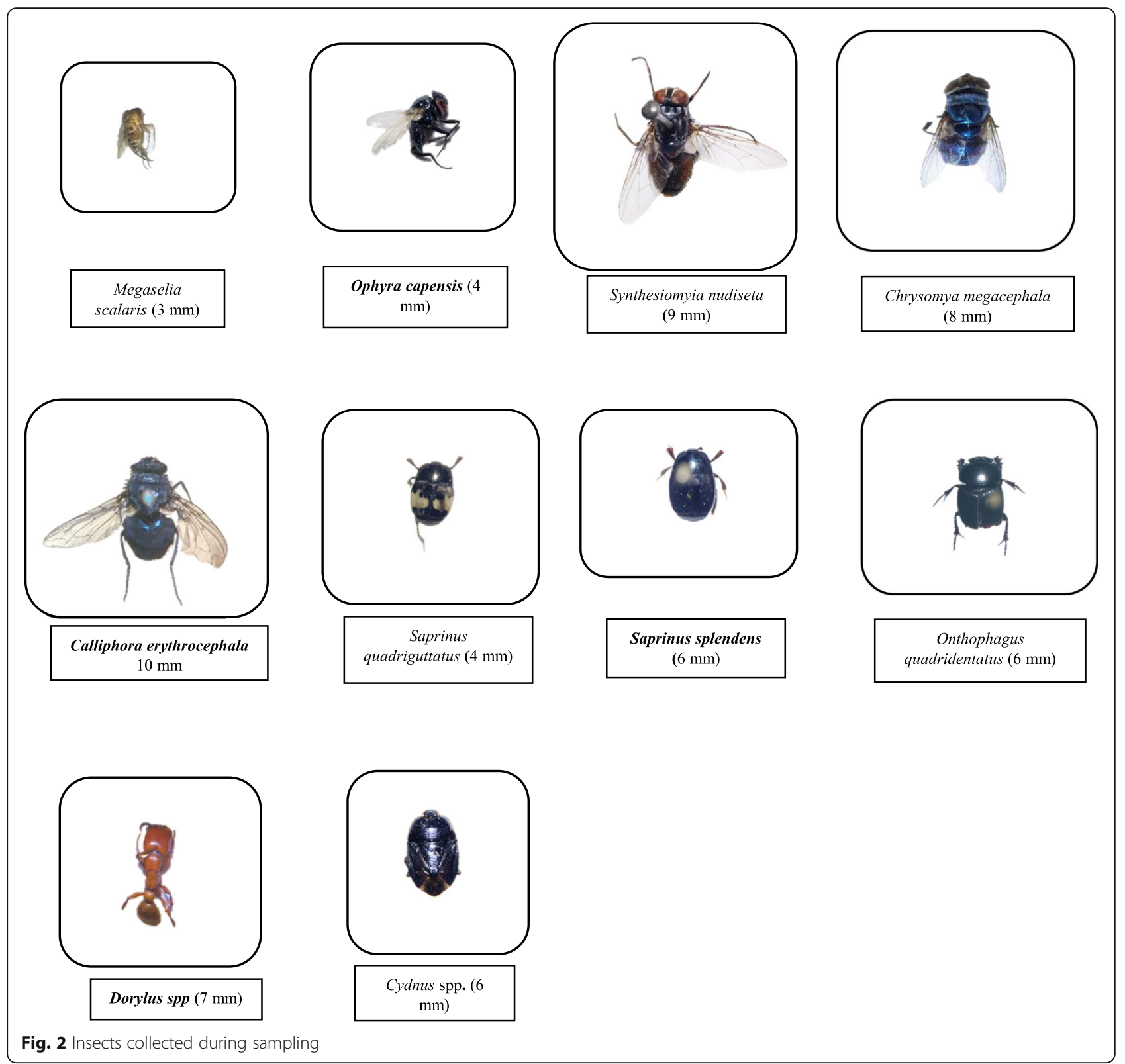

Hydrotaea capensis (Muscidae) were found in large numbers in the deflated abdominal region, the active decay stage inside and outside of the abdomen within the grave.

Furthermore, adults of Dorylus sp., Saprinus quadriguttatus, and Saprinus splendens were also collected during the third sampling ( 3 weeks after burial). In the active-decay stage, aggregation of ants (Dorylus sp.) was observed on the goat where maggots were found feeding. In the post-decay stage during the fourth sampling (4 weeks after burial), most of the body mass had been decomposed, larvae of $H$. capensis were still observed with cocoons of $S$. nudiseta inside the grave. From the fifth sampling onwards, the body was in the dry stage. Very few larvae of $H$. capensis and many cocoons of $H$. capensis and $S$. nudiseta were found during the fifth sampling. Live cocoons and empty puparial cases were collected during the sixth sampling. Empty puparia were found on seventh and eighth sampling. From the ninth sampling onwards, no fauna was detected till the last sampling (thirteenth).

The summary of results with the date of sampling, fauna collected, site of collection during sampling has been provided in Table 1. The images of stages of decomposition of goat carcass and insects collected during 


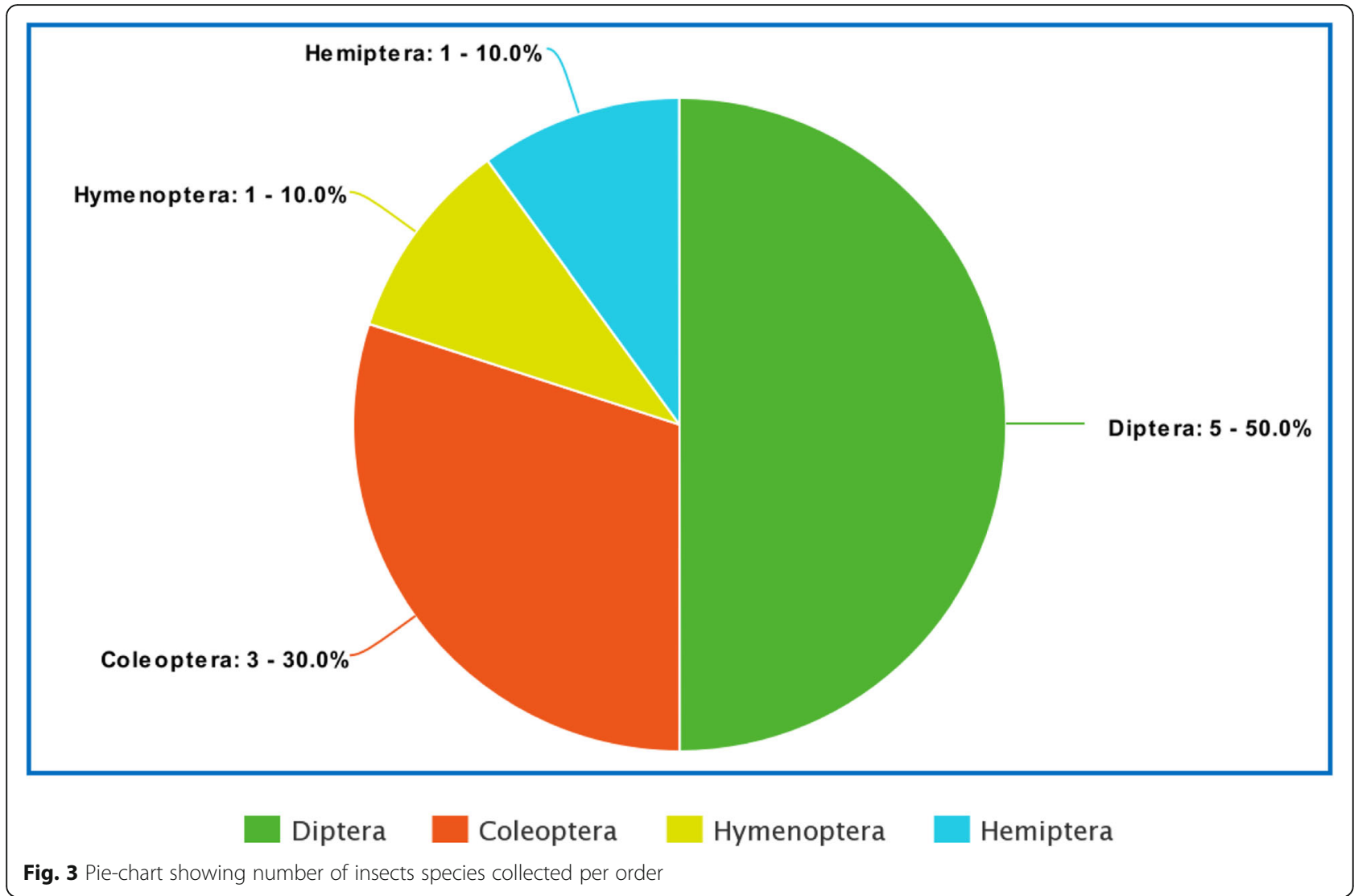

sampling have been provided in Figs. 1 and 2, respectively. A pie chart showing the number of species collected per order is shown in Fig. 3.

\section{Discussion}

Insects are attractive to body fluids like urine, saliva, and fecal material oozing from natural openings and blood from wounds. However, the presence of larvae in these locales is a common phenomenon in exposed bodies lying above the ground (Beneckea et al. 2009). In the current study, it has been observed that no maggots were found on the wounded region of the neck and the other natural orifices of the goat (video clip 2 in supplementary files). This is probably due to the obliteration of bodily fluid and blood from wounds and natural orifices by the soil cover. The presence of maggots on the body beneath the ground is presumably due to the reasons that:

1. The flies oviposited on the grave's surface, and after hatching, larvae crawled and reached the target.

2. The adults had access to the corpse by burrowing through the soil.

3. The flies oviposited during brief exposure of goat carcass at the time of sampling.
Meanwhile, many calliphorids were found visiting the carcass during the sampling and exploring the resource but could not oviposit as no eggs or larvae were recorded on/in the body. It was also observed that at optimal temperature between $28{ }^{\circ} \mathrm{C}$ and $32{ }^{\circ} \mathrm{C}$, the insect activity was maximum. As the temperature progressed, we found that immature stages have completed part of their life cycle.

The usual fly families that are considered as a typical carrion fauna are Calliphoridae, Sarcophagidae, and Muscidae. In the current study, Dipterans of Muscidae, Calliphoridae, and Phoridae families were collected. The larvae of two muscid species, i.e., Hydrotaea capensis and Synthesiomyia nudiseta, are recorded, dominant in the decay process. Megaselia scalaris, was found consistently on two sampling dates beneath the ground on the goat carcass and was also seen running on the grave's surface. M. scalaris, H. capensis, and S.nudiseta can be critical forensic indicators in the cases of buried bodies. The two species mentioned above have also been found inside the coffin and mummified bodies (Morrow et al. 2015).

Necrophagous beetles are either predatory on the larvae feeding on the carcasses or associated with the feeding on hairs and skin. Saprinus spp. of Histeridae, collected, is of forensic relevance and reported from 
most carcasses (Shayya et al. 2018). It has also been reported on the goat carcass above ground at Kullu, Himachal Pradesh, India (Singh and Bala 2019) and on a buried piece of pork at $60 \mathrm{~cm}$ in Punjab, India (Bala and Kaur, 2015). Dung beetles of the subfamily Scarabaeinae are a functionally important group of invertebrates that use both dung and carrion (Vernes et al. 2005). The scarabaeid beetle Onthophagous sp. reported from the current study has also been reported from other carrion resources such as the chicken liver and dead goat (Tshikae et al. 2008; Singh and Bala 2019).

Hymenoptera, particularly ants, associated with exposed carrion and are generally represented by Pheidole megacephala or Dorylus species, although others may also occur (Ekanem and Dike 2010). In the current study, Dorylus sp. were found beneath the ground, feeding on the maggots and decaying flesh. This ant species has also been reported from a decaying rabbit at Patiala (Singh and Bharti, 2001). Ants also have a burying behavior of covering the carcass by soil with soil particles, preventing flies and beetles from colonizing the corpse (Singh et al. 2020).

Others have reported species from buried corpses such as Fannia canicularis, Muscina stabulans, Ophyra aenescens, and Megaselia scalaris on an exhumed infant skeleton in Argentina (Mariani et al. 2017). Calliphora vicina, C.vomitoria, Lucilia sericata, Muscina stabulans, and Muscina prolapsa have been reported to colonize buried remains at different depths (Gunn and Bird 2011). C. vicina and C. vomitoria were found to be attracted and oviposited through different zips of various gauge sizes of suitcases enclosing bait (Bhadra and Hart, 2014). Clothing also affects carcass decomposition and the pattern of insect succession. In a study in Western Australia, clothed pig carcass has more larval masses of L. sericata and Australophyra rostrata widely distributed than unclothed ones (Voss et al. 2011). In addition, the researches dealing with the seasonality of succession patterns in the same region reported that different dominant species and their arrival time vary in different seasons (Watson and Carlton 2005). There is little known about the buried corpse entomofauna from India. A study on a buried piece of pork from the state of Punjab is the only study reported from India, which reported only beetles (Bala and Kaur 2015). There are more studies on open lying carcasses than buried ones. There should be more exploration of buried corpses to get a more comprehensive data of insects that are able to colonize at different depths of burials and at different geographical regions of India.

\section{Conclusion}

Buried forensic entomology needs more exploration, especially in India, as the data is scanty. And more extensive studies need to be performed to develop a geographical database on arthropod succession from different habitats with applications in forensic and ecological fields. The current study provides basic information in the field of buried forensic entomology. However, we conclude that some insects can colonize buried carcasses, which requires more exploration and research in this direction.

\section{Abbreviations}

C: Calliphora; H: Hydrotaea; L: Lucilia; M: Megaselia; RH: Relative humidity; S: Synthesiomyia; Sp.: Species

\section{Supplementary Information}

The online version contains supplementary material available at https://doi. org/10.1186/s41935-021-00235-5.

Additional file 1: Video clip 1.

Additional file 2: Video clip 2.

\section{Acknowledgements}

We gratefully acknowledge the Diptera Section of Zoological Survey of India, Kolkata, for its support to confirm the identified species of Diptera, Coleoptera, Hemiptera, and Hymenoptera mentioned in the article.

Authors' contributions

SS performed the experiment and was a major contributor in writing the manuscript. AQ analyzed and interpreted the data, finalized the manuscript. Both authors read and approved the final manuscript.

Funding

This research did not receive any specific grant from funding agencies.

Availability of data and materials

Not applicable

\section{Declarations}

Ethics approval and consent to participate

We procured a dead goat at Dhorra mafi, Aligarh, Uttar Pradesh, India, for this experiment. Hence, ethical consideration was not required.

Consent for publication

Not applicable

Competing interests

The authors declare that they have no competing interests.

Received: 21 April 2021 Accepted: 25 August 2021

Published online: 04 September 2021

\section{References}

Anderson GS (1999) Wildlife forensic entomology: determining time of death in two illegally killed black bear cubs. J Forensic Sci. 44(4):856-859

Bala M, Kaur P (2015) Insect faunal succession on buried piece of pork in the state of Punjab (India): a Preliminary Study. J Forensic Res 6:252. https://doi. org/10.4172/2157-7145.1000252

Beneckea M, Josephib E, Zweihoffb R (2009) Neglect of the elderly: forensic entomology cases and consideration. Forensic Sci Int 146:S195-S199. https:// doi.org/10.1016/j.forsciint.2004.09.061.

Bhadra P, Hart AJ, Hall MJR (2014) Factors affecting accessibility to blowflies of bodies disposed in suitcases. Forensic Sci Int 239:62-72. https://doi.org/10.1 016/j.forsciint.2014.03.020

De Carvalho C, Mello-Patiu C (2008) Key to the adults of the most common forensic species of Diptera in South America. Rev Bras Entomol. 52:390-406. https://doi.org/10.1590/S0085-56262008000300012 
Ekanem MS, Dike MC (2010) Arthropod succession on pig carcasses in South Eastern Nigeria. Pap Avulsos Zool (Sao Paulo) 50(35):561-570. https://doi. org/10.1590/S0031-10492010003500001

Gunn A, Bird J (2011) The ability of the blowflies Calliphora vomitoria (Linnaeus), Calliphora vicina (Rob-Desvoidy) and Lucilia sericata (Meigen) (Diptera: Calliphoridae) and the muscid flies Muscina stabulans (Fallén) and Muscina prolapsa (Harris) (Diptera: Muscidae) to colonise buried remains. Forensic Sci Int 207:198-204. https://doi.org/10.1016/j.forsciint.2010.10.008

Hagstrum D, Athanassiou C (2019) Improving stored product insect pest management: from theory to practice. Insects. 10(10):332. https://doi.org/1 0.3390/insects 10100332

Keshavarzi D, Rassi Y (2020) Diversity of public health and forensic important flies using three measures of hill numbers in Iran. Open Public Health J 13:497502. https://doi.org/10.2174/1874944502013010497

Keshavarzi D, Zaimy MA, Yusuf MA, Shahriarinamadi M, Parkhideh S (2019) Insect succession on carrion in Fars Province, southwestern Iran. Egypt J Forensic Sci 9(1):18. https://doi.org/10.1186/s41935-019-0124-8

LeBlanc K, Boudreau DR, Moreau G (2021) Small bait traps may not accurately reflect the composition of necrophagous Diptera associated to remains. Insects 12(3):261. https://doi.org/10.3390/insects12030261

Mariani R, García-Mancuso R, Varela G, Kierbel I (2017) New records of forensic entomofauna in legally buried and exhumed human infants remains in Buenos Aires, Argentina. J Forensic Leg Med 52:215-220. https://doi.org/10.1 016/j.jflm.2017.09.012

Morrow JJ, Baldwin DA, Higley L, Piombino-Mascali D, Reinhard KJ (2015) Curatorial implications of Ophyra capensis (Order Diptera, Family Muscidae) puparia recovered from the body of the Blessed Antonio Patrizi, Monticiano, Italy (Middle Ages). J Forensic Leg Med 36:81-83. https://doi.org/10.1016/j. jflm.2015.09.005

Sawaby RF, Hamouly HE, Abo-El Ela RH (2018) Diagnosis and keys of the main dipterous families and species collected from rabbit and guinea pig carcasses in Cairo, Egypt. JoBAZ 79:10. https://doi.org/10.1186/s41936-0180018-6

Shayya S, Dégallier N, Nel A, Azar D, Lackner T (2018) Contribution to the knowledge of Saprinus Erichson, 1834 of forensic relevance from Lebanon (Coleoptera, Histeridae). ZooKeys 738:117-152. https://doi.org/10.3897/ zookeys.738.21382

Singh D, Bharti M (2001) Ants (Hymenoptera: Formicidae) associated with decaying rabbit carcasses. Uttar Pradesh J Zool 21:93-94

Singh N, Bala M (2019) Succession study on forensically important Coleoptera from India: a preliminary study and its forensic implications. Egypt J Forensic Sci 9:66. https://doi.org/10.1186/s41935-019-0168-9

Singh S, Abdullah NAB, Carbaugh J, Heo CC (2020) Ants associated with a rat carcass: its implications in forensic entomology with special emphasis on Carebara diversa (Hymenoptera: Formicidae). Int J Trop Insect Sci 40:703706. https://doi.org/10.1007/s42690-020-00110-1

Tshikae B.P, Adrian L. V. Davis, Clarke H. Scholtz, (2008) Trophic associations of a dung beetle assemblage (Scarabaeidae: Scarabaeinae) in a Woodland Savanna of Botswana. Environ Entomol 37(2):431-441. https://doi.org/10.1 093/ee/37.2.431

Vernes K, Pope LC, Hill CJ, Barlocher F (2005) Seasonality, dung specificity and competition in dung beetle assemblages in the Australian Wet Tropics, northeastern Australia. J Trop Ecol 21(1):1-8. https://doi.org/10.1017/S02664 $6740400224 X$

Voss SC, Cook DF, Dadour IR (2011) Decomposition and insect succession of clothed and unclothed carcasses in Western Australia. Forensic Sci Int 211 (13):67-75. https://doi.org/10.1016/j.forsciint.2011.04.018

Watson EJ and Carlton CE (2005) Insect succession and decomposition of wildlife carcasses during fall and winter in Louisiana. J Med Entomol 42:193-203. https://doi.org/10.1603/0022-2585(2005)042[0193:isadow]2.0.co;2

\section{Publisher's Note}

Springer Nature remains neutral with regard to jurisdictional claims in published maps and institutional affiliations.

\section{Submit your manuscript to a SpringerOpen ${ }^{\circ}$ journal and benefit from:}

- Convenient online submission

Rigorous peer review

- Open access: articles freely available online

- High visibility within the field

- Retaining the copyright to your article

Submit your next manuscript at $\boldsymbol{\nabla}$ springeropen.com 